\title{
PENGEMBANGAN INSTRUMEN LAGRANGIAN \\ GPS DRIFTER COMBINED (GERNED) UNTUK OBSERVASI LAUT
}

\author{
DEVELOPMENT OF LAGRANGIAN INSTRUMENT \\ GPS DRIFTER COMBINED (GERNED) FOR OCEAN OBSERVATION
}

\author{
Noir P. Purba1, Syawaludin A. Harahap ${ }^{1}$, Donny J. Prihadi ${ }^{1}$, Ibnu Faizal ${ }^{1}$, Putri G. Mulyani ${ }^{1}$, Candra A. Fitriadi ${ }^{1}$, \\ Isnan F. Pangestu ${ }^{1}$, Prio D. Atmoko², Adam Alfath², Joshua T. Sitio ${ }^{3}$ \\ ${ }^{1}$ Departemen Ilmu Kelautan, Fakultas Perikanan dan Ilmu Kelautan, Universitas Padjadjaran \\ ${ }^{2}$ Departemen Fisika, Fakultas Matematika dan Ilmu Pengetahuan Alam, Universitas Padjadjaran \\ ${ }^{3}$ Departemen Pertanian dan Biosistem, Fakultas Teknologi Industri Pertanian, Universitas Padjadjaran \\ FPIK-UNPAD, Kampus Jatinangor, Jl. Ir. Sukarno Km. 21 \\ Bandung, Jawa Barat 45363, Telp: 022-87701519, Faks: 022-87701518 \\ e-mail : noir.purba@unpad.ac.id
}

Diterima tanggal: 14 September 2017 ; diterima setelah perbaikan: 7 November 2017 ; Disetujui tanggal: 12 Desember 2017

\begin{abstract}
ABSTRAK
Instrumen Lagrangian telah banyak digunakan untuk pengumpulan data arus laut dan observasi di perairan Indonesia membutuhkan data yang langsung dapat diketahui (real time). Kajian ini menekankan pada pengembangan GPS Drifter Combined (GERNED) dari sisi desain dan sistem pengukuran. Hasil pengujian menunjukkan bahwa GERNED dapat digunakan di danau, perairan dangkal, dan laut terbuka. Konstruksi terdiri dari bahan akrilik, Polyethylene, dan aluminium. Desain konstruksi terdiri dari bagian atas sebagai penutup dan juga tempat sensor udara dan lampu indikator, bagian tengah yang merupakan pusat mikro-kontroller, catu daya, sensor-sensor, penyimpanan data manual dan pengiriman data via satelit. Biaya yang dibutuhkan untuk membuat alat ini sekitar 15.000.000 (lima belas juta rupiah) dengan biaya terbesar adalah kontrol pengiriman data. Pada bagian bawah merupakan baling-baling statik. Pengujian yang dilakukan di laboratorium untuk melihat posisi lokasi sudah menunjukkan data yang sama dengan data lapangan sedangkan untuk pengujian lapangan yang dilakukan di pulau Untung Jawa menunjukkan bahwa arah dan pergerakan GERNED sama dengan pergerakan float tracking umumnya.
\end{abstract}

Kata kunci: Instrumen, lagrangian, GPS Drifter, GERNED, observasi laut.

\section{ABSTRACT}

Lagrangian instrument has been widely used for collection data of ocean currents and observations in Indonesian waters requires data that can be real time. This study emphasizes the development of GPS Drifter Combined (GERNED) in terms of design and measurement systems. Test results showed that GERNED can be used in lakes, shallow waters, and open seas. Construction consists of acrylic material, Polyethylene, and aluminum. The construction design consists of the top as a cover and also the air sensor and indicator lights, the central part which is the center of the micro-controller, power supply, sensors, manual data storage and data transmission via satellite. The cost needed about 15,000,000 (fifteen million rupiah) with the highest cost is the control of data transmission. At the bottom is a static propeller. Testing conducted in the laboratory to see the location position has shown the same data with field data while for field testing conducted on the island of Untung Java shows that the direction and movement of GERNED equals the movement of float tracking generally.

Keywords: Instrument, lagrangian, GPS Drifter, GERNED, ocean observation.

\footnotetext{
Pengembangan Instrumen Lagrangian GPS Drifter Combined (Gerned) untuk Observasi Laut - Noir P. Purba, Syawaludin A. Harahap, Donny J. Prihadi, Ibnu Faizal, Putri G. Mulyani, Candra A. Fitriadi, Isnan F. Pangestu, Prio D. 


\section{PENDAHULUAN}

Deskripsi variabilitas kolom air dan sistem dinamiknya harus mencakup informasi tentang keadaan statik dan kinetikanya (Griffa et al., 2007). Salah satu metode in situ terbaik untuk mengetahui kondisi dinamik suatu perairan adalah dengan mengukur arus laut. Pengukuran arus dengan metode Lagrangian (Yeung $\&$ Pope, 1988) telah lama diterapkan untuk mengukur pola, arah, dan asal arus (Davis, 1991; Mullarney \& Henderson, 2013). Pendekatan dengan konsep lagrangian adalah dengan mengikuti atau melacak gerak air spesifik secara ruang dan waktu (Schacht \& Lemckert, 2007). Salah satu instrumen lagrangian yakni GPS (Global Positioning System) drifter atau float tracking merupakan instrumen yang sudah lama digunakan untuk melacak arus (Spencer et al., 2014). Dalam beberapa tahun terakhir, pengembangan instrumen pengukur arus telah digunakan di lautan secara global untuk mempelajari dinamika termasuk untuk stratifikasi kolom air (Lange \& Sebille, 2017). Konsep Lagrangian sudah digunakan untuk beberapa aplikasi seperti penyebaran larva plankton (Cowen et al., 2006), rekruitmen planula terumbu karang (Cetina-Heredia et al., 2015; Fitriadi et al., 2016), pencemaran laut termasuk sampah dan polusi minyak (Lebreton et al., 2012), fronts (Song et al., 1995) dan sebaran nutrien (Jönsson et al., 2011; Qin et al., 2016).

Secara teori bahwa desain dari GPS Drifter harus berfungsi dengan baik dengan mengedepankan teknologi dan sesuai dengan karakteristik partikel air (Huhn et al., 2012). Pengembangan ini sudah dilakukan oleh beberapa peneliti (Stommel, 1949; Swallow, 1955; Austin \& Atkinson, 2004), dengan menambahkan GPS didalamnya (George \& Largier, 1996), memodifikasi desain (Spencer et al., 2014; Jannssen \& de Koning, 2015), dan data dapat ditransfer secara real time (Perez et al., 2003). Untuk melihat berbagai contoh float tracking dapat dilihat di www.aoml.noaa.gov/phod /dac/gdp_ drifter.php. Sejak pengembangan GPS Drifter sudah dilakukan di berbagai negara dan perusahaan, namun di Indonesia pengembangan ini masih jarang dilakukan $(<5$ konstruksi) dan hanya terbatas pada pengukuran arus. Kekurangan dari instrumen yang telah ada adalah sinyal pengirim data yang tidak real time, harga yang mahal, dan hanya mencakup 1 parameter saja. Indonesia merupakan negara dengan karakteristik yang kompleks, sehingga informasi biologi, kimia, dan fisis perairan sangat penting. Pengukuran dengan kapal dirasa sangat mahal dan membutuhkan waktu yang lama. Untuk itu, kajian ini sendiri akan menekankan pada pengembangan pengukur arus yang dinamakan dengan GERNED (GPS Drifter Combined). Alat ini didesain dengan sederhana, harga yang murah, dan dapat digunakan untuk perairan Indonesia yang kompleks. Kelebihan dari alat ini adalah dapat digunakan pada perairan dangkal $(<1$ meter), perairan umum daratan, dan laut terbuka. GERNED juga dikombinasikan dengan sensor temperatur air dan udara, konduktivitas, $\mathrm{pH}$, kelembapan udara. Instrumen ini juga didesain untuk mengirimkan data secara real time dan dapat digunakan selama beberapa hari hingga bulanan. Diharapkan, dalam jangka panjang, instrumen ini dapat menjadi alat pengukur standar untuk perairan Indonesia sehingga diharapkan dapat mengumpulan data sebanyak mungkin dengan biaya yang murah.

\section{BAHAN DAN METODE}

\section{Konstruksi dan Material}

Konstruksi GERNED berdasarkan filosofis dari propagul mangrove yang dapat melayang di perairan sebelum mencapai tempat yang cocok (settlement area). Selain itu, endekatan untuk desain ini adalah dengan melihat beberapa desain pelampung yang telah digunakan seperti ARGO Float (Pranowo et al., 2005), float profiling lainnya, dan GPS drifter. Alat ini merupakan pengembangan dari instrument sebelumnya dimana kelemahan dari GERNED tahap 1 adalah desain yang tidak stabil, tidak terdapat sensor atmosfer, dan juga data hanya dapat disimpan dalam memory card. Instrumen ini akan fokus pada tiga hal yakni pengukuran arus, pengukuran fisis dan kualitas perairan, dan kondisi atmosfer. Kontruksi GERNED dibagi menjadi beberapa hal inti, pertama, sketsa desain, perancanngan struktur, dan pemilihan material. Kedua, memeriksa sensor dan memperkirakan volume total dan kemudian menghitung kestabilan dan gaya apung. Ketiga, mencetak kerangka dan baling-baling. Keempat, bagian pengujian dan kelayakan. Ukuran permukaan mengapung dan drogue bervariasi, dengan rasio area terseret 40 . Dengan rasio slip arah angin yang dihasilkan adalah $0,7 \mathrm{~cm} / \mathrm{s}$ dalam $10 \mathrm{~m} / \mathrm{s}$ angin (Niiler \& Paduan, 1995; Pazan \& Niiler, 2001). Kemudian, berat GERNED diseuaikan dengan berat standar yakni sekitar $20 \mathrm{~kg}$.

Instrumen ini terdiri dari tiga bagian utama yakni bagian atas (sensor atmosfer dan penutup), bagian utama (mikro-kontroller, sensor dan catu daya) dan bagian bawah yakni baling-baling statik (Gambar 1). Total tingginya adalah $145 \mathrm{~cm}$ dengan diameter $17 \mathrm{~cm}$ pada bagian utama. Lambung utama badan GERNED terbuat dari alumunium setebal 0,3-0,4 $\mathrm{mm}$ dengan 


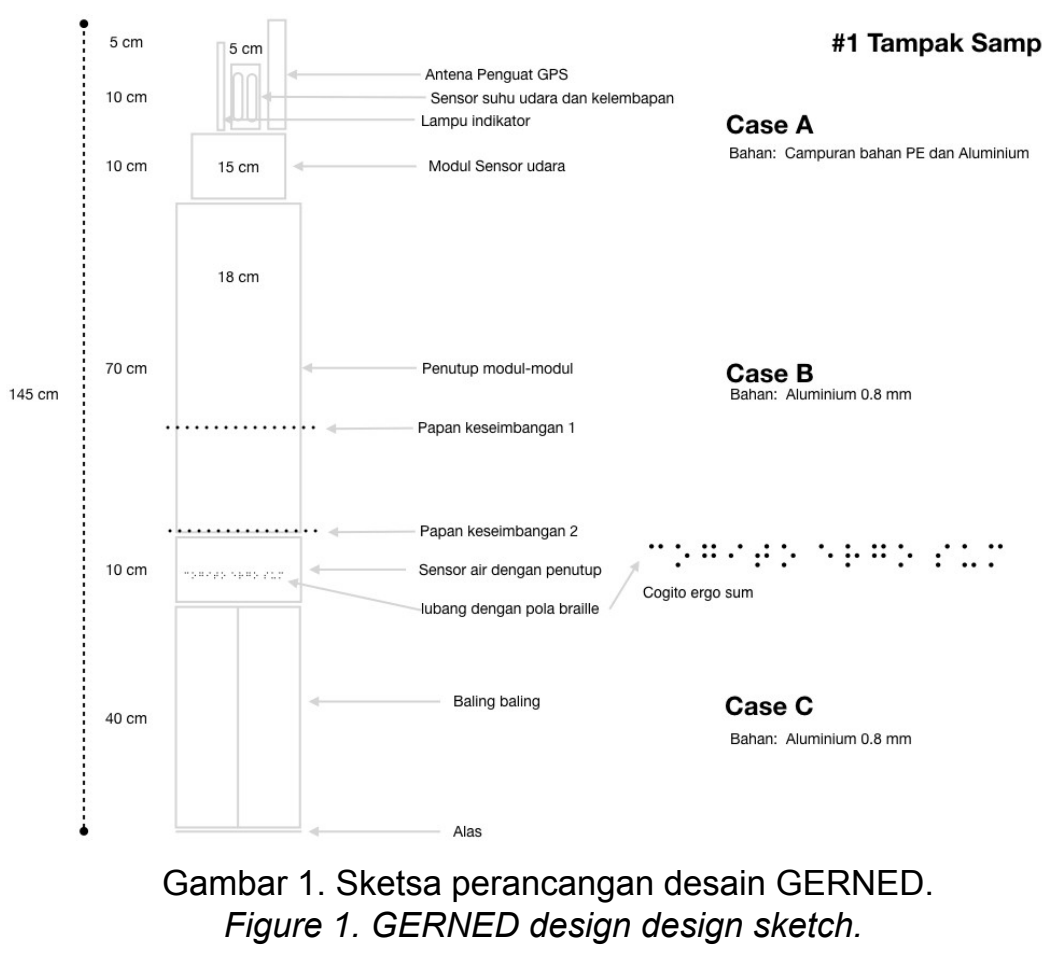

panjang $70 \mathrm{~cm}$. Bagian bawah (baling-baling) dan bagian atas terbuat dari akrilik dan pvc. GERNED berisi baterai di dalam diode-protected packs, $24 \mathrm{D}$-cell batteries, memory card, alat untuk transmisi data ke satelit, seperangkat sensor tekanan udara dan kelembapan, salinitas, $\mathrm{pH}$, dan konduktivitas.

Desain GERNED dirancang untuk dapat digunakan pada perairan dangkal dengan penambahan papan keseimbangan pada bagian bawah disamping sensor berada. Untuk itu, case $\mathrm{C}$ dapat dilepas sehingga ketikda digunakan pada perairan dangkal, akan ditambahkan papan keseimbangan. Secara umum perancangan sistem transmit data GPS dan sensor dengan menggunakan sistem satelit. Penggunaan sistem ini membangun kerja GERNED yang lebih optimal terutama untuk memenuhi kualitas data di tempat-tempat yang tidak terjangkau sinyal terutama di perairan Indonesia. Namun alat ini juga dilengkapi dengan memori card internal untuk mendukung penyimpanan data secara manual. Bagian Case $A$ merupakan penutup dan tempat sensor kelembapan dan suhu udara yang dilengkapi dengan indikator lampu dan juga penutup utama (Gambar 2). Pada Case $B$ merupakan tempat mikrokontroller, catu daya, satelit transmitter, micro $s d$, dan sensor-sensor yang terletak pada bagian bawah. Sensor sensor yang dipasang berada sekitar $0,5 \mathrm{~m}$ dari permukaan perairan.

Denah mikro-kontroller di desain seefisien mungkin dengan mengatur penempatan setiap komponen. Penempatan mikro-kontroller di dalam badan
GERNED adalah di bagian tengah, hal ini diharapkan dapat mencegah kerusakan pada sistem utama ini jika terjadi kecelakaan. Terdapat segmen di bagian atas dan bawah tiang tempat mikro-kontroller ditempatkan, sehingga keamanannya lebih terjamin.

\section{Sensor-sensor}

Ada 8 sensor yang dipasang pada GERNED dan merupakan sensor portable yang didapatkan dari berbagi sumber. Sensor-sensor tersebut dicari via online dan merupakan sensor yang terstandarisasi. Untuk pengiriman data secara real time digunakan RockBLOCK 11297 dari sparkfun electronics sebagai sarana untuk pengiriman data melalui satelit (Tabel 1).

\section{Pengujian-pengujian}

Pengujian yang paling utama adalah pengukuran arus. Hal ini dikarenakan desain yang dibuat berbeda dengan desain sebelunya. Selanjutnya dilakukan dengan beberapa tahap: 1) Uji sensor, 2) uji pengukuran arus, 3) uji parameter lainnya. Uji laboratorium dilakukan untuk melihat kekuatan daya tahan baterai, stabilitas, data dari sensor, sinyal GPS, dan kesinambungan data. Selanjutnya pengujian lapangan dilakukan pada 1-4 November 2017 di Pulau Untung Jawa yang merupakan bagian dari gugusan Kepulauan Seribu di Teluk Jakarta $\left(-5.976343^{\circ}, 106.703604^{\circ}\right)$. Pemilihan lokasi ini dikarenakan arus yang relatif tenang (Sachoemar, 2008) sehingga tes ini dapat dipantau secara terus menerus. Tes ini berguna untuk melihat stabilitas 


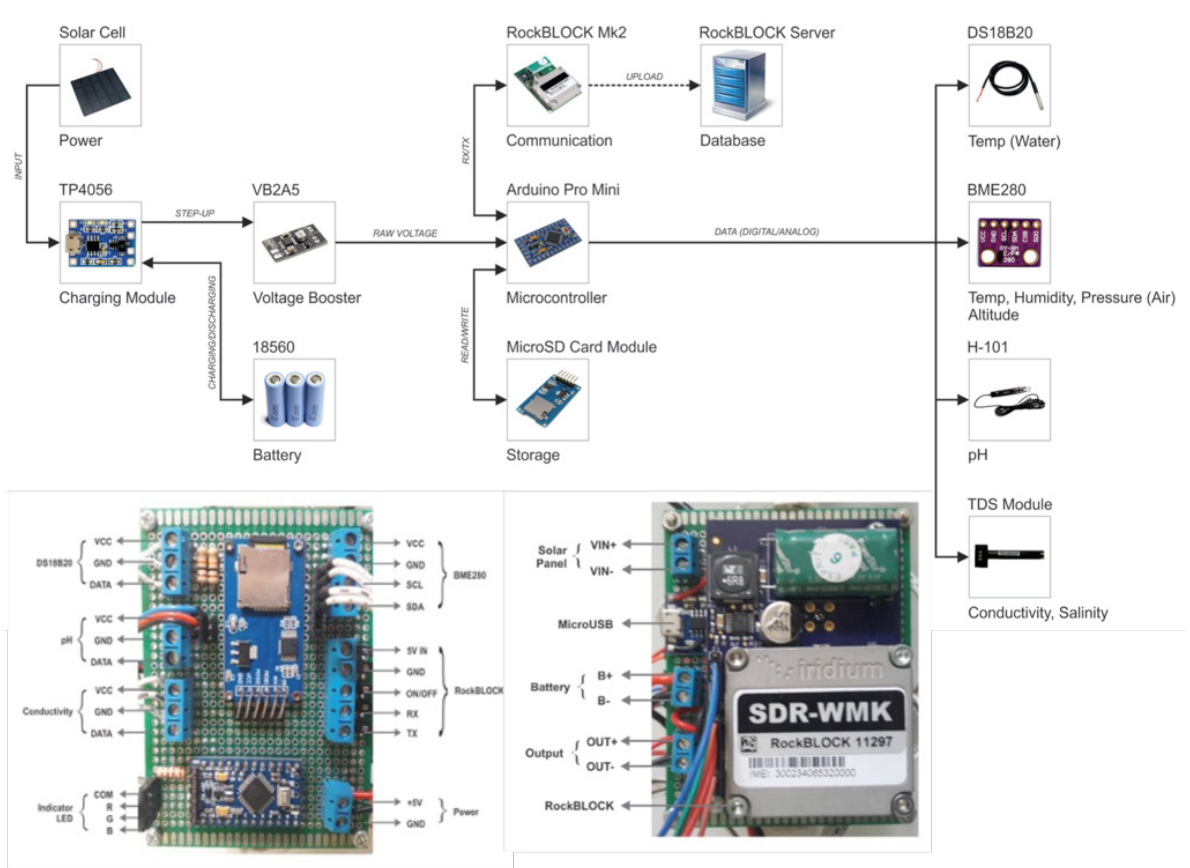

Gambar 2. Sistem Mikro-Kontroller dan Sirkuit.

Figure 2. Micro-Controller and Circuit System.

GERNED di perairan. Instrumen ini akan diujibandingkan dengan float tracking dan juga Artifical Debris (AD) yang dilengkapi dengan GPS. AD merupakan botol kecil yang didalamnya dipasang GPS tracker TK102-2 dengan sinyal transmisi GSM dan tingkat akurasi 10 meter.

\section{HASIL DAN PEMBAHASAN}

\section{Desain}

Fokus pertama pada penelitian ini adalah pada desain GERNED yang terjangkau. Total biaya GERNED kira-kira Rp. 15.000.000 (lima belas juta rupiah) dengan biaya terbesar ada pada data transfer kontroller. Selanjutnya, komponen mekanis utama drifter adalah float permukaan, tether, dan drogue, seperti yang ditunjukkan pada skematik Gambar 3. Desain instrumen ini mempunyai berat sekitar $20 \mathrm{~kg}$ dengan komponen yang paling berat berada di baling-baling $(\sim 16 \mathrm{~kg})$. Hal ini berguna agar instrumen ini lebih stabil dan tidak dipengaruhi oleh angin. Pemilihan akrilik dan aluminium dikarenakan bahan ini tahan terhadap korosi dan mudah didapatkan dengan harga yang relatif terjangkau.

Gambar 2 (kiri) menunjukkan GERNED saat dilepas dan (kanan) saat dirakit seluruhnya. Agar antara sensor dan penutup utama tidak terjadi kebocoran, maka dipasang o-ring. Pengujian selanjutnya dilakukan dengan melihat indicator lampu untuk sinyal GPS dan saluran transmisi sensor. Terdapat dua lampu yang dipasang pada GERNED dimana satu lampu berada di dalam untuk melihat apakah sensor dan mikrokontroller sudah dalam keadaan menyala, dan satu lagi diletakkan di bagian atas sebagai indikator untuk pencarian sinyal (Gambar 4).

Ada tiga indikator lampu yakni berwarna merah bahwa tidak terdapat sinyal, warna hijau adalah sedang mencari sinyal, dan biru menandakan siap untuk digunakan. Pada percobaan di laboratorium, bahwa waktu dari warna merah ke biru memakan waktu 2 detik, namun akan tergantung pada kondisi ruangan (tertutup atau terbuka).

\section{Uji Ketahanan dan Kelayakan Hasil Ujicoba Laboratorium}

Pengujian pengiriman data dengan RockBLOCK (transfer satelit) dilakukan dengan melihat tes penerimaan posisi dan juga hasil posisi yang didapatkan oleh google earth di wilayah Jatinangor. Pengiriman data dapat dilakukan dengan interval detik, menit, dan jam tergantung kebutuhan. Untuk alat ini, data pengukuran disimpan terlebih dahulu pada media penyimpanan (memory card) dan kemudian dapat ditransfer via satelit. Tidak terdapat perbedaan penunjukan lokasi diantara keduanya, sehingga dapat disimpukan bahwa posisi yang ditunjukkan oleh RockBLOCK dapat digunakan. Selanjutnya, pengujian kestabilan alat dilakukan di kolam simulasi. 
Tabel 1. Sensor dan Spesifikasinya

Table 1. Sensors and Specifications

\begin{tabular}{lllll}
\hline No. & Sensor & Presisi & Perusahaan & Keterangan \\
\hline 1 & GPS & Higher timing accuracy & U-Blox & Time pulse $0,25-10 \mathrm{MHz}$ \\
2 & Temperatur udara & $2{ }^{\circ} \mathrm{C}$ & Adafruit & Range $:-40-85^{\circ} \mathrm{C}$ \\
3 & Temperatur air DS 18820 & $0,1^{\circ} \mathrm{C}$ & & Probe stainless steel \\
4 & Konduktivitas & & DF Robot & \\
5 & pH & $7 \pm 0,5$ & SFE Electronics & Range : $0-14$ \\
6 & Kelembapan & & Adafruit & Range $: 0-100$ \\
7 & Altimeter & $\pm 1 \mathrm{M}$ & Adafruit & $0-9,2 \mathrm{~km}$ dari permukaan laut \\
8 & Tekanan Udara (APM) & 12 & Adafruit & $30.000-110.000 \mathrm{~Pa}$ \\
\hline
\end{tabular}

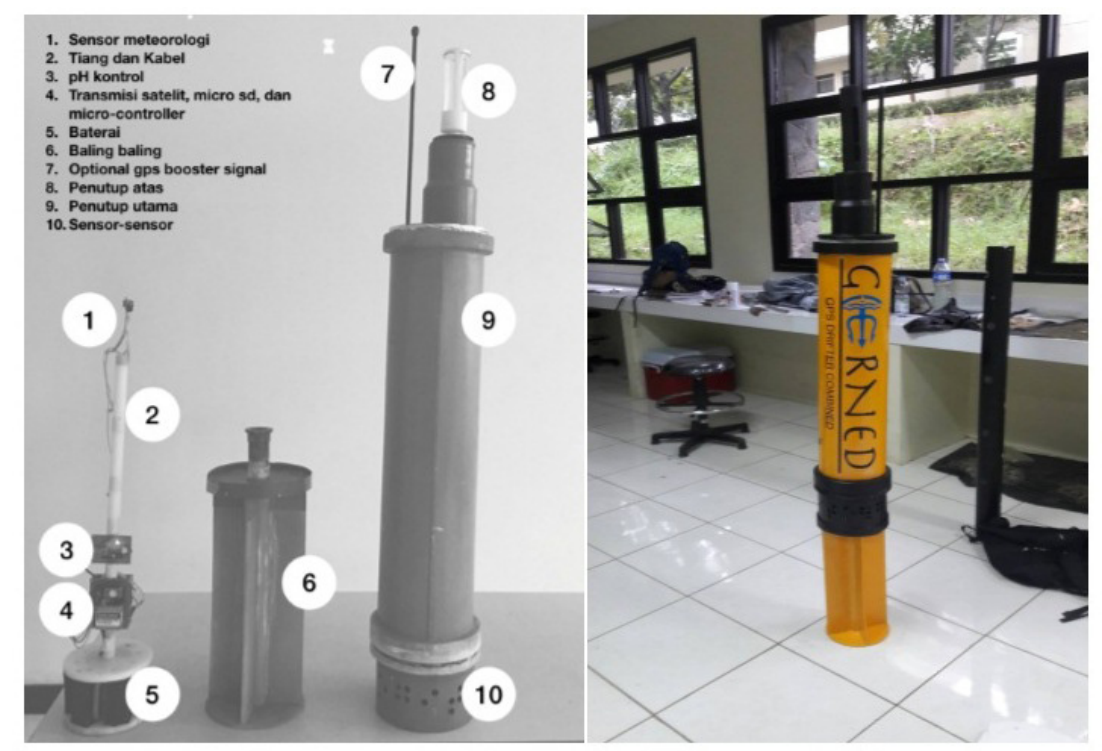

Gambar 3. Desain GERNED.

Figure 3. GERNED Design.

Hasil menunjukkan bahwa terdapat kemiringan alat dikarenakan berat pada bagian bawah yang masih kurang (14 kg) sehingga kemudian ditambahkan piringan dengan berat sekitar $6 \mathrm{~kg}$. Penambahan beban ini membuat GERNED stabil dan dapat tegak lurus. Hal ini sesuai dengan penelitian sebelumnya yang menyatakan bahwa berat float drifter untuk ukuran mini sekitar $20 \mathrm{~kg}$ (Lumpkin \& Pazos, 2007).

\section{Hasil Ujicoba Lapangan}

Pengujian lapangan dilakukan di sekitar Pulau Untung Jawa (PUJ) Kepulauan Seribu, DKI Jakarta pada tanggal 3 Desember 2017. Pengujian dilakukan untuk melihat arah dan kecepatan GERNED dibandingkan dengan float tracking standar dan juga Artifical Debris (AD) yang dilengkapi dengan GPS. Hasil uji coba di perairan Untung Jawa dapat dilihat pada Tabel 2.

Pengujian dilakukan selama hampir 1 jam yakni dimulai pada pukul 09.30 WIB dan berakhir pada pukul 10.30 WIB. Untuk AD sendiri hanya dilakukan selama 10 menit (09.36-09.46 WIB). Hasil pengujian menunjukkan bahwa terdapat perbedaan kecepatan diantara ketiga instrumen dimana kecepatan GERNED lebih cepat dibandingkan dengan float tracking dan $\mathrm{AD}$, namun memiliki arah yang sama. Kecepatan ketiga alat ini berkisar antara 0,35-0,19 m/s. Kajian ini hampir sama dengan penelitian yang dilakukan oleh Yuliasari et al., 2012 di sekitar teluk Jakarta dengan kecepatan rerata $0,123 \mathrm{~m} / \mathrm{s}$ dan hasil penelitian Setiawan, 2016 sekitar 0,2-0,3. Ketiga alat ini juga sesuai dengan arah angin yang berasal dari barat daya menuju ke timur laut dan berbelok ke utara. Perbedaan kecepatan lebih diakibatkan pada pada saat pengujian masih terjadi Badai Dahlia sehingga pergerakan ketiga instrumen lebih cepat. Kecepatan angin pada bulan Monsun Barat bervariasi antara 7-20 knot dan bertiup dari barat daya sampai ke barat laut (Sachoemar, 2008). Pengujian di lapangan dilakukan pada saat awal memasuki Monsun Barat sehingga efek dari Monsun Peralihan II masih ada dan mempengaruhi kondisi arus di perairan tersebut. 
Tabel 2. Sensor dan spesifikasinya

Table 2. Sensors and Specifications

\begin{tabular}{lllllll}
\hline Jenis Tracker & Tanggal & $\begin{array}{l}\text { Mulai } \\
\text { (WIB) }\end{array}$ & $\begin{array}{l}\text { Berhenti } \\
\text { (WIB) }\end{array}$ & \multicolumn{2}{l}{$\begin{array}{l}\text { Waktu Tempuh Jarak Tempuh } \\
\text { (detik) }\end{array}$} & $\begin{array}{l}\text { Kecepatan } \\
\text { (m) }\end{array}$ \\
\hline Float Tracking
\end{tabular}

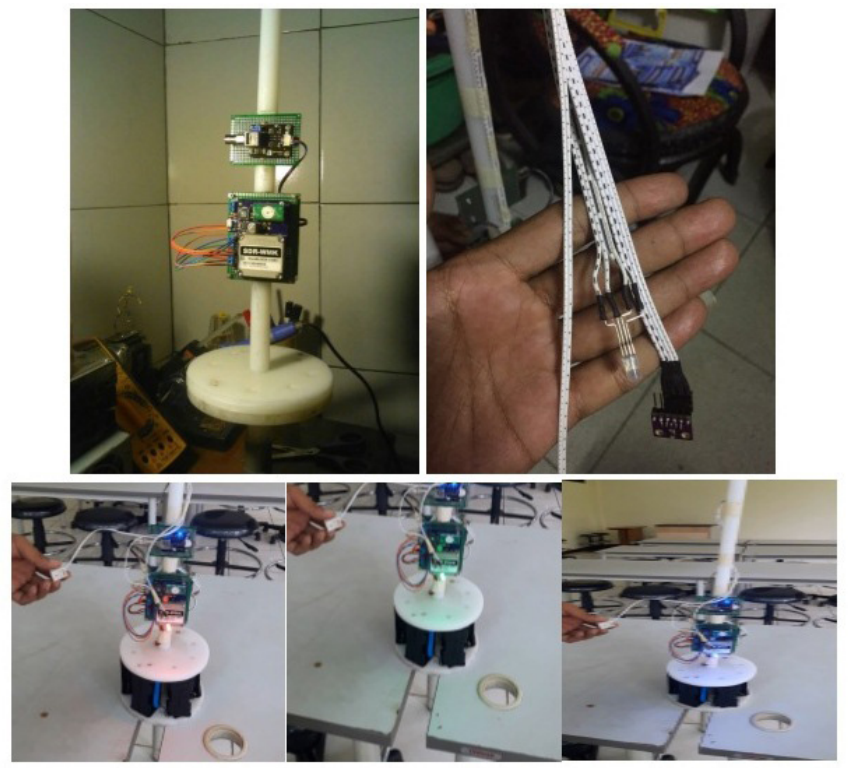

Gambar 4. Visualisasi Sinyal Transmisi Data, (atas kiri-kanan) Mikro-Kontroller dan Sensor Atmosfer Serta Lampu Indikator, (bawah) Lampu Indikator Untuk Proses Pencarian Sinyal.

Figure 4. Visualization of Data Transmission Signals (top left-right) Micro-Controller and Atmospheric Sensor and Indicator Light, (below) Indicator Lamp For Signal Search Process.

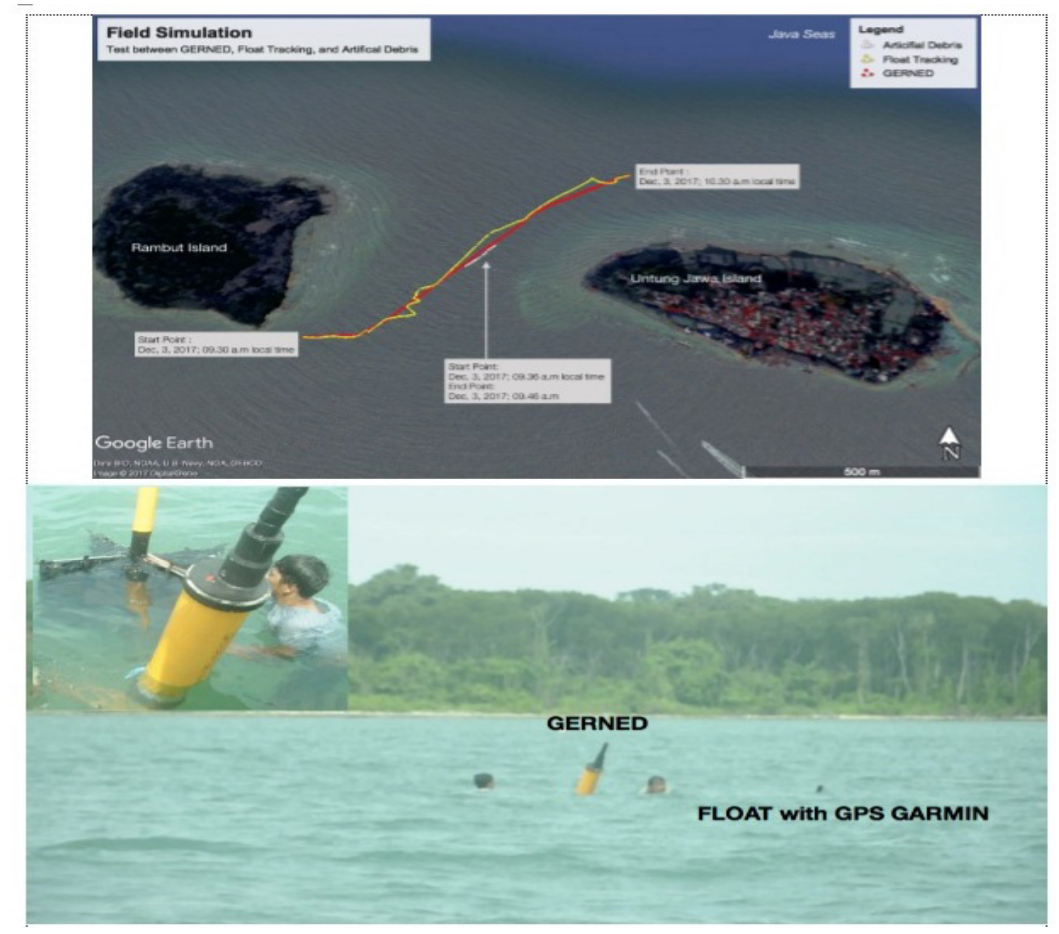

Gambar 4. Hasil Tracking GERNED dan Float Tracking di Untung Jawa. Figure 4. Results of GERNED Tracking and Float Tracking in Untung Java. 
Kondisi angin di Kepulauan Seribu dipengaruhi sistem monsoon.

Peletakan ketiga alat dilakukan di barat dari PUJ dan mendekati Pulau Rambut. Perairan di sekitar pulau ini sekitar 30-40 $\mathrm{m}$ dengan arus permukaan yang didominasi oleh angin dan pasang surut (Lubis \& Yosi, 2012). Perubahan arah arus lebih disebabkan oleh kontur kepulauan dan juga kondisi perairan Teluk Jakarta (Gambar 5).

Terjadinya perbedaan kecepatan GERNED dan float tracking lebih diakibatkan oleh luasan tabung yang berada diatas permukaan laut lebih terpengaruh oleh angin jika dibandingkan luasan float tracking dengan rasio (3:1). Pengaruh angin masih mempengaruhi pergerakan alat jika dilihat dari hasil pengujian. Kemudian, selama pengujian, baterai yang dipasang sekitar 6 buah li-on lithium yang dapat di isi ulang, dan masih dapat berfungsi, namun pada saat kajian ini tidak dihitung tingkat daya baterai pada saat di lapangan. Pada skenario dengan menggunakan komposisi panel surya plus 5 baterai Lithium $6800 \mathrm{mAh}$. Panjang operasional instrumen GERNED secara teori dengan daya tahan yang lama (harian dan bulanan). Skenario dengan sel surya dapat memenuhi kebutuhan daya setiap hari dimana tenaga yang dihasilkan dari sel surya adalah $60.000 \mathrm{~mW}$ dan daya yang dibutuhkan adalah $60.000 \mathrm{~mW}$. Penambahan baterai ini diperlukan sebagai kekuatan cadangan yang meningkat dari 5 baterai dengan kekuatan $100.640 \mathrm{~mW}$. Akan tetapi, ruang yang ada di GERNED untuk pemasangan sel surya bisa mengganggu tingkat keseimbangan. Berdasarkan skenario dengan sel surya, waktu beroperasi dihitung selama 24 hari. Namun pada saat ini, pengujian dengan panel surya belum dilakukan mengingat akan mengubah keseimbangan GERNED.

\section{KESIMPULAN DAN SARAN}

Instrumen ini mempunyai konstruksi yang dapat mengukur arus sekaligus parameter lainnya dengan biaya murah dan tahan lama. Penggunaan alat ini juga dapat menggantikan survei laut yang mementingkan data permukaan. Alat ini juga mudah dioperasikan dengan tidak memerlukan keahlian khusus. GERNED telah berhasil diuji coba di laut dangkal di perairan Untung Jawa dengan waktu tempuh selama satu jam didapatkan jarak tempuh sejauh $1.260 \mathrm{~m}$, dengan modifikasi yang dilakukan pada desain baling-baling dan penambahan sensor-sensor. Pengembangan dengan penambahan sensor termasuk pengujian baterai harus dilakukan dengan mempertimbangkan daya tahan baterai dan kestabilan alat. Pengujian pada danau belum dilakukan sehingga diperlukan pengujianpengujian lanjutan untuk memberikan gambaran yang utuh terkait aplikasinya. Walaupun selama pengujian di lapangan telah dilakukan bersamaan dengan sampah laut, namun perlu pada tahapan jenis sampah dengan berbagai bobot yang berbeda.

\section{UCAPAN TERIMA KASIH}

Penelitian ini merupakan Hibah Internal Universitas Padjadjaran (HIU) pada tahun 2017. Penulis mengucapkan terima kasih kepada James Manning dari NOAA (National Oceanographic Atmospheric and Administration) untuk diskusi tentang desain global. Alat ini dibuat di Laboratorium Teknologi Kelautan-FPIK. Selain itu, terima kasih kepada Luthfi Fauzan Akuan, Cynthia Mutiara S, Sapta, Wisnu, Titan, Fadlyian, Kemal, Salafy, Mreward, Yuki Pratama, yang telah membantu selama pembuatan dan uji di lapangan.

\section{DAFTAR PUSTAKA}

Austin, J., \& Atkinson, S. 2004. The Design and Testing of Small, Low-cost GPS-tracked. Journal Estuaries, vol. 27, No. 6, p 1026-1029

Cetina-Heredia, P., Roughan, M., van Sebille, E., Feng, M., \& Coleman, M. A. (2015). Strengthened currents override the effect of warming on lobster larval dispersal \& survival, Glob. Change Biol., 21, 43774386.

Cowen, R. K., Paris, C. B., \& Srinivasan, A. (2006). Scaling of connectivity in marine populations, Science, 311, $522-527$.

Davis, R. E. (1991). Lagrangian ocean studies. Annu. Rev. Fluid Mech. 23, 43-64.

Fitriadi, C. A., Dhahiyat Y., Purba, N. P., Harahap, S. A., \& Prihadi, D.J. (2016). Planula Recruitment Based on Oceanography Condition in Rakit Islands-Indonesia. Prooc. Biodiversitas, Jatinangor-Indonesia

George, R., \& J. Largier. (1996). Description and performance of nescale drifters for coastal and estuarine studies. $J$. Atmos. Ocean. Technology, 13, 1322-1326.

Green, A. N., \& Cooper, J. A. G. (2014). Lagrangian Drifter Approach. Proceedings $13^{\text {th }}$ International Coastal Symposium (Durban, South Africa), Journal of Coastal Research, Special Issue No. 70, pp. 029-034, ISSN 0749-0208.

Griffa, A., Kirwan, D., Mariano, A., Ozgokmen, T., \& Rossby, T. (2007). Lagrangian Analysis and Prediction of Coastal and Ocean Dynamics. Cambridge University, $1-38$.

Huhn, F., von Kameke, A., Allen-Perkins, S., Montero, P., Venancio, A., \& Pérez-Munuzuri, V. (2012). Horizontal Lagrangian transport in a tidal-driven 
estuary-Transport barriers attached to prominent coastal boundaries. Continental Shelf Research, 39$40,1-13$.

Jannssen, M., \& de Koning, R. (2015). Feasibility of Velocity Measurements by a Drifer in the Yangon River. Delft University of Technology, 1-9

Jönsson, B.F., Döös, K., Myrberg, K., \& Lundberg, P.A. (2011). A Lagrangian-trajectory study of a gradually mixed estuary. Continental Shelf Research, 31, 18111817.

Lange M., \& E. van Sebille. (2017). Parcels v0.9: prototyping a Lagrangian ocean analysis framework for the petascale age. Geosci. Model Dev., 10, 4175-4186, 2017, https://doi.org/10.5194/gmd-10-4175-2017

Lebreton, L. C. M., Greer, S. D., \& Borerro, J. C. (2012). Numerical modeling of floating debris in the world's oceans, Mar. Pollut. Bull., 64, 653-661.

Lubis, A., \& Yosi, M. (2012). Kondisi Meteorologi Maritim dan Oseanografi di Perairan Sekitar Pulau Kotok, Kepulauan Seribu: April 2011. Jurnal Ilmu dan Teknologi Kelautan Tropis, Vol. 4, No. 1, Hl. 24-34

Lumpkin, R., \& Pazos, M. (2007). Measuring surface currents with Surface Velocity Program drifters: the instrument, its data, and some recent results. Lagrangian Analysis and Prediction of Coastal and Ocean Dynamics. Cambridge UniversityPress. Pp. 39-67

Mullarney, J. C \& Henderson, S. M. (2013). A Novel drifter designed for use with a mounted Acoustic Doppler Current Profiler in shallow environments. Limnol. Oceanography: Methods 11, 438-449. DOI 10.4319/ lom.2013.11.438

Perez, J.C., Bonner, J., Kelly, F.J., \& Fuller, C. (2003). Development of a Cheap, GPS-Based, Radio-Tracked, Surface Drifter for Closed Shallow-Water Bays. Proc. Of the IEEE/OES Seventh Working Conference on Current Measurement Technology

Pranowo, W. S., Phillips, H., \& Wiffles, S. (2005). Upwelling Event 2003 Along South Java Sea and Lesser Sunda Islands. Journal Segara, Vol. 1 No. 3

PRTK [Pusat Riset Teknologi Kelautan]. (2008). Kaji Terap Sistem Observasi Lingkungan Laut Terpadu. Laporan. 223 Hal.

Qin, X., Menviel, L., Sen Gupta, A., \& van Sebille, E. (2016). Iron sources and pathways into the Pacific Equa- torial Undercurrent, Geophys. Res. Lett., 43, 9843-9851, https://doi.org/10.1002/2016GL070501

Sachoemar, S. I. (2008). Karakteristik Lingkungan Perairan Kepulauan Seribu. JAI Vol. 4, No. 2

Setiawan, A.S. (2016). Simulasi Model Hidrodinamika dan Dispersi Termal di Teluk Jakarta Pra dan PascaReklamasi 17 Pulau. Laporan Teknis, 24 Hal.

Song, T., Rossby, T., \& Carter, E. Jr. (1995). Lagrangian studies of fluid exchange between the Gulf Stream and surrounding waters. J. Phys. Oceanogr., 25, 4663.

Spencer, D., Lemckert, C.J., Yu, Y., Gustafson, J., Lee, S.Y., \& Zhang, H. (2014). Quantifying Dispersion in an Estuary: A Lagrangian Drifter Approach. Proceedings 13th International Coastal Symposium
(Durban, South Africa), Journal of Coastal Research, Special Issue No. 70, pp. 029-034, ISSN 0749-0208.

Stommel, H. (1949). Horizontal difusion due to oceanic turbulence. J. Mar. Res., 8, 199-255

Swallow, J. (1955). A neutral-buoyancy float for measuring deep currents. Deep Sea Res., 3, 74-81.

Yuliasari, D., Zainuri, M., \& Sugianto, D. N. (2012). Kajian Pola Arus di Pantai Marina Ancol dan Pengaruhnya Terhadap Rencana Reklamasi. Buletin Oseanografi Marina, Vol. 1, 1-9.

Yeung, P. K., \& Pope, S. B. (1988). An Algorithm for Tracking Fluid Particles in Numerical Simulations of Homogeneous Turbulence, Journal of Computational Physics vol. 79, 373-416.

JURNAL KELAUTAN NASIONAL, Vol. 12, No 3, Desember 2017, Hal. 109-116 